\title{
Oordelen over beroepsopleidingen in het MBO
}

Citation for published version (APA):

Verhagen, A. M. C., \& Meng, C. M. (2014). Oordelen over beroepsopleidingen in het MBO. ROA. ROA Fact Sheets No. 003 https://doi.org/10.26481/umarof.2014003

Document status and date:

Published: 01/01/2014

DOI:

10.26481/umarof.2014003

Document Version:

Publisher's PDF, also known as Version of record

\section{Please check the document version of this publication:}

- A submitted manuscript is the version of the article upon submission and before peer-review. There can be important differences between the submitted version and the official published version of record.

People interested in the research are advised to contact the author for the final version of the publication, or visit the DOI to the publisher's website.

- The final author version and the galley proof are versions of the publication after peer review.

- The final published version features the final layout of the paper including the volume, issue and page numbers.

Link to publication

\footnotetext{
General rights rights.

- You may freely distribute the URL identifying the publication in the public portal. please follow below link for the End User Agreement:

www.umlib.nl/taverne-license

Take down policy

If you believe that this document breaches copyright please contact us at:

repository@maastrichtuniversity.nl

providing details and we will investigate your claim.
}

Copyright and moral rights for the publications made accessible in the public portal are retained by the authors and/or other copyright owners and it is a condition of accessing publications that users recognise and abide by the legal requirements associated with these

- Users may download and print one copy of any publication from the public portal for the purpose of private study or research.

- You may not further distribute the material or use it for any profit-making activity or commercial gain

If the publication is distributed under the terms of Article $25 \mathrm{fa}$ of the Dutch Copyright Act, indicated by the "Taverne" license above, 
U. Maastricht University in Learning!

Research Centre for Education and the Labour Market | ROA

\section{Oordelen over beroepsopleidingen in het MBO}

\section{ROA Fact Sheet}

ROA-F-2014/3

Researchcentrum voor Onderwijs en Arbeidsmarkt | ROA Research Centre For Education and the Labour Market / ROA 


\section{Inleiding}

De laatste jaren wordt het steeds belangrijker gevonden dat aankomend MBO-studenten goed geïnformeerd zijn over hun toekomstige opleiding. Het gaat daarbij bijvoorbeeld over de tevredenheid van studenten, of de kans op het vinden van een stageplaats of werk. Dit factsheet richt zich op het eerste aspect: de oordelen van recent MBO-gediplomeerden over verschillende aspecten van de gevolgde MBO-opleiding. Dit doen we voor 132 grote beroepsopleidingen'. De term 'beroepsopleiding' wordt hier gebruikt voor een cluster van crebo-opleidingen. Hierbij wordt gebruik gemaakt van de koppeltabel zoals door OCW/DUO, Inspectie van het Onderwijs, SBB en MBO-Raad ontwikkeld. Door alleen de grote beroepsopleidingen te selecteren verliezen we 79 kleine beroepsopleidingen uit de dataset, die $2 \%$ van alle respondenten vertegenwoordigen. De resultaten in dit factsheet zijn gebaseerd op ruim 30.600 respondenten.

In de tekst worden de resultaten beschreven per opleidingssector, en aan het einde van het factsheet zijn de resultaten voor alle 132 beroepsopleidingen te vinden. Daarbij wordt ook de sector waartoe de beroepsopleiding behoort, de niveaus waarop de beroepsopleiding door de respondenten gevolgd is, en het percentage gediplomeerden dat die beroepsopleiding in het BBL volgde vermeld. Het is belangrijk om het percentage BBL'ers te laten zien, omdat het aandeel BBL-gediplomeerden binnen een beroepsopleiding positief en significant samenhangt met positieve oordelen over de opleiding en sterk negatief en significant samenhangt met negatieve oordelen over de opleiding. In andere woorden worden beroepsopleidingen met een groot aandeel BBL-gediplomeerden in de regel minder negatief beoordeeld dan beroepsopleidingen met een groot aandeel BOL-gediplomeerden.

\section{Voorbereiding arbeidsloopbaan}

\section{Starten op de arbeidsmarkt}

Beroepsopleidingen dienen jongeren rechtstreeks voor te bereiden op de arbeidsmarkt en hen wat dit betreft start bekwaam te maken. Gemiddeld is $41 \%$ van de gediplomeerden van mening dat hun opleiding een (heel) goede basis biedt om te starten op de arbeidsmarkt. Ongeveer een kwart is daarentegen van mening dat hun opleiding wat betreft het starten op de arbeidsmarkt (helemaal) geen goede basis biedt (zie tabel 1).

1. Voor dit factsheet is een 'grote' beroepsopleiding gedefinieerd als een beroepsopleiding waarvan minstens 20 gediplomeerden van het schooljaar 2011/2012 hebben deelgenomen aan de enquête.
Tabel 1

Oordeel over de mate waarin de gevolgde opleiding een goede basis biedt om te starten op de arbeidsmarkt, per opleidingssector (\%)

\begin{tabular}{lrr}
\hline & \multicolumn{2}{c}{ Starten op de arbeidsmarkt } \\
& $\begin{array}{c}\text { (Helemaal) geen goede } \\
\text { basis }\end{array}$ & (Heel) goede basis \\
\hline Landbouw & 25 & 38 \\
Techniek & 20 & 44 \\
Economie & 26 & 36 \\
Gezondheidszorg & 18 & 50 \\
Gedrag\&Maatschappij & 33 & 32 \\
& & \\
Totaal & 23 & 41 \\
\hline
\end{tabular}

Gemiddeld zijn de gediplomeerden van opleidingen in de opleidingssector Gezondheidszorg het vaakst positief en het minst vaak negatief over de voorbereiding die hun opleiding biedt voor het starten op de arbeidsmarkt: $50 \%$ is van mening dat het een (heel) goede basis biedt, en 'slechts' $18 \%$ is van mening dat het wat dit betreft (helemaal) geen goede basis biedt. In Bijlage 1 is te zien dat van de beroepsopleidingen binnen de sector Gezondheidszorg het oordeel over de basis om te starten op de arbeidsmarkt het beste is voor de beroepsopleiding Tandartsassistent (72\% (heel) goede basis). Toch worden niet alle beroepsopleidingen in de sector Gezondheidszorg goed beoordeeld: van de gediplomeerden van de beroepsopleiding Sport en bewegen vindt $24 \%$ dat de opleiding een (heel) goede basis biedt om te starten op de arbeidsmarkt en $40 \%$ dat het wat dit betreft (helemaal) geen goede basis biedt.

Op de tweede plaats wat betreft de basis om te starten op de arbeidsmarkt staat de opleidingssector Techniek. Van alle 132 beroepsopleidingen oordelen gediplomeerden van de technische beroepsopleidingen Optiek en Koopvaardij officier alle schepen het vaakst positief over de basis om te starten op de arbeidsmarkt (beide $83 \%$ (heel) goede basis). Daarentegen wordt de technische beroepsopleiding Game artist van alle beroepsopleidingen het slechtst beoordeeld (o\% (heel) goede basis, $80 \%$ (helemaal) geen goede basis).

De opleidingssector Gedrag\&Maatschappij wordt gemiddeld het slechtst beoordeeld wat betreft de basis om te starten op de arbeidsmarkt. Binnen deze opleidingssector wordt de beroepsopleiding Sociaal-maatschappelijk dienstverlener het vaakst slecht beoordeeld (58\% (helemaal) geen goede basis).

\section{Verder ontwikkelen kennis en vaardigheden}

Naast het direct start bekwaam maken van de studenten - de korte termijn doelstelling van het onderwijs - dienen opleidingen ook een basis te bieden voor het verder ontwikkelen van kennis en vaardigheden in het vervolg van de (onderwijs) carrière. In tabel 2 is te zien dat het oordeel over dit aspect van de gevolgde opleiding doorgaans (nog) beter is dan het oordeel over de basis om te starten op de arbeidsmarkt. De meerderheid van de gediplomeerden (55\%) is van mening dat de gevolgde opleiding een (heel) goede basis biedt voor het verder ontwikkelen van kennis en vaardigheden. Van 
alle 132 beroepsopleidingen wordt de technische beroepsopleiding Operationele techniek het vaakst goed beoordeeld met betrekking tot de basis voor het verder ontwikkelen van kennis en vaardigheden ( $89 \%$ (heel) goede basis) (zie Bijlage 1). De technische beroepsopleiding Interieuradviseur wordt daarentegen het vaakst slecht beoordeeld ( $28 \%$ (helemaal) geen goede basis).

Tabel 2

Oordeel over de mate waarin de gevolgde opleiding een goede basis biedt voor het verder ontwikkelen van kennis en vaardigheden, per opleidingssector (\%)

\begin{tabular}{lrr}
\hline & \multicolumn{2}{c}{$\begin{array}{c}\text { Verder ontwikkelen kennis en vaardigheden } \\
\text { (Helemaal) }\end{array}$} \\
& $\begin{array}{c}\text { geen goede } \\
\text { basis }\end{array}$ & (Heel) goede basis \\
\hline Landbouw & 15 & 51 \\
Techniek & 12 & 55 \\
Economie & 14 & 51 \\
Gezondheidszorg & 9 & 63 \\
Gedrag\&Maatschappij & 14 & 53 \\
Totaal & 12 & 55 \\
\hline
\end{tabular}

Wederom is het de opleidingssector Gezondheidszorg die gemiddeld het beste wordt beoordeeld: $63 \%$ is van mening dat de opleiding die in deze sector werd gevolgd een (heel) goede basis biedt voor het verder ontwikkelen van kennis en vaardigheden. Binnen deze opleidingssector is het de beroepsopleiding Verzorgende-IG die het beste wordt beoordeeld ( $73 \%$ (heel) goede basis).

Hoewel het verschil met de andere opleidingssectoren niet groot is, worden de opleidingssectoren Landbouw en Economie gemiddeld het slechtst beoordeeld wat betreft de basis voor het verder ontwikkelen van kennis en vaardigheden. Binnen Landbouw is Recreatiedieren de beroepsopleiding die het vaakst slecht wordt beoordeeld ( $24 \%$ (helemaal) geen goede basis). Binnen de economische opleidingssector worden de beroepsopleidingen Productiecoördinator fashion ${ }^{2}$ en Applicatie- en mediaontwikkeling het slechtst beoordeeld (beide 26\% (helemaal) geen goede basis).

\section{Selectiviteit}

Om een beeld te krijgen van de selectiviteit van de opleidingen is de respondenten gevraagd om op een schaal van 1-5 aan te geven in hoeverre ze het eens waren met de volgende stellingen:

- De docenten waren streng in de beoordeling van cursisten

- Het niveau van de leerstof was goed

- Het niveau van de opleiding was uitdagend

- De examens/opdrachten waren over het algemeen zeer pittig

- In de opleiding werd voldoende getoetst op inzicht

2. Er zijn tevens crebo's die onder de beroepsopleiding Productiecoördinator fashion vallen, die tot de opleidingssector Techniek behoren.
De oordelen over deze vijf stellingen hangen sterk met elkaar samen en laten een hoge mate van interne consistentie zien. We kunnen daarom het gemiddelde oordeel over deze vijf stellingen berekenen. We dienen er overigens rekening mee te houden dat het gaat om de subjectieve oordelen van de schoolverlaters die de opleiding succesvol hebben afgerond. Het zegt daardoor meer over de selectiviteit tijdens de opleiding dan over de selectiviteit bij intrede. Studenten die de opleiding vanwege tegenvallende studieresultaten voortijdig hebben verlaten zullen waarschijnlijk heel anders denken over de mate van selectiviteit tijdens de opleiding. Niettemin geeft deze indicator een goed beeld van de mate waarin de gevolgde opleiding, naar het oordeel van de schoolverlaters zelf, selectief was.

In tabel 3 is te zien dat gediplomeerden gemiddeld iets vaker aangeven dat ze de opleiding niet selectief was (33\% (helemaal) mee eens) dan dat het dat wel was (27\% (helemaal) mee eens). Van alle onderzochte beroepsopleidingen wordt de technische beroepsopleiding Vliegtuigonderhoud het vaakst selectief gevonden (58\% (helemaal) mee eens) (zie Bijlage 1). De technische beroepsopleiding Game artist wordt daarentegen het vaakst niet selectief gevonden $(71 \%$ (helemaal) mee oneens).

Tabel 3

Oordeel over de selectiviteit van de opleiding, per opleidingssector (\%)

\begin{tabular}{lrr}
\hline & \multicolumn{2}{c}{ De opleiding was selectief } \\
& (Helemaal) mee oneens & (Helemaal) \\
\hline Landboe eens \\
Techniek & 31 & 26 \\
Economie & 30 & 29 \\
Gezondheidszorg & 35 & 26 \\
Gedrag\&Maatschappij & 30 & 31 \\
& 40 & 23 \\
Totaal & & 27 \\
\hline
\end{tabular}

De opleidingssector Gezondheidszorg wordt met $31 \%$ gemiddeld het vaakst selectief gevonden. De beroepsopleiding Apothekersassistent wordt van alle Gezondheidszorgopleidingen het vaakst selectief gevonden (46\% (helemaal) mee eens).

Gemiddeld wordt de opleidingssector Gedrag\&Maatschappij het vaakst niet selectief gevonden (40\% (helemaal) mee eens). Van de gediplomeerden van de beroepsopleiding Maatschappelijke zorg is zelfs meer dan de helft (52\%) van mening dat de opleiding niet selectief is.

\section{Tevredenheid}

De respondenten is gevraagd aan te geven in hoeverre ze, terugkijkend naar hun gevolgde BOL/BBL-opleiding, tevreden zijn met een tiental aspecten van hun gevolgde opleiding. Deze aspecten zijn op basis van analyses van de correlatie en interne consistentie gereduceerd tot drie clusters (zie tekstbox 1).

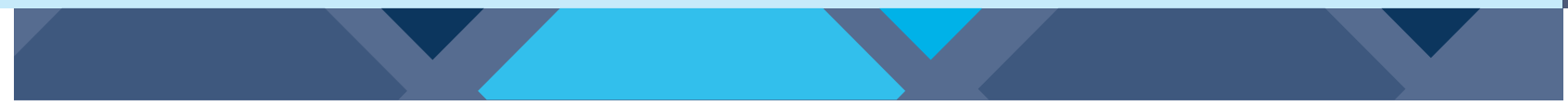




\section{Tekstbox 1}

Clusters van aspecten van de opleiding waarvan de mate van tevredenheid is gemeten

\section{Inhoud}

- Inhoud van de vakken

- Hoeveelheid praktijk

- Manier van examineren

- De kwaliteit van de examens

\section{Begeleiding}

- Voorlichting over studie- en beroepsmogelijkheden

- (Studie)begeleiding

\section{Docenten}

- Manier waarop leraren lesgeven

- De kwaliteit van docenten

\section{Tevredenheid met de inhoud}

Van de totale groep gediplomeerden is gemiddeld iets minder dan de helft (48\%) (zeer) tevreden over de inhoud, maar $17 \%$ is (zeer) ontevreden over dit aspect van de gevolgde opleiding (zie tabel 4). Van alle onderzochte beroepsopleidingen zijn de gediplomeerden van de technische beroepsopleiding Assistent logistiek medewerker veruit het meest tevreden over de inhoud (91\% (zeer) tevreden; 0\% (zeer) ontevreden) (zie Bijlage 2). Gediplomeerden van de economische beroepsopleiding Mediamanagement zijn daarentegen het minst tevreden over de inhoud (43\% (zeer) ontevreden).

Tabel 4

Mate van tevredenheid over de inhoud, per opleidingssector (\%)

\begin{tabular}{lcr}
\hline & $\begin{array}{c}\text { Inhoud } \\
\text { (Zeer) ontevreden }\end{array}$ & (Zeer) tevreden \\
\hline Landbouw & 15 & 51 \\
Techniek & 16 & 47 \\
Economie & 18 & 47 \\
Gezondheidszorg & 15 & 51 \\
Gedrag\&Maatschappij & 17 & 47 \\
& & \\
Totaal & 17 & 48 \\
\hline
\end{tabular}

Hoewel de verschillen tussen de opleidingssectoren klein zijn, zijn de gediplomeerden in de opleidingssectoren Landbouw en Gezondheidszorg gemiddeld het vaakst tevreden over de inhoud (51\% (zeer) tevreden). Van de beroepsopleidingen in de opleidingssector Landbouw zijn de gediplomeerden van Assistent medewerker voedsel en leefomgeving het vaakst (zeer) tevreden over de inhoud (65\%). Binnen de opleidingssector Gezondheidszorg zijn de gediplomeerden van Apothekersassistent het vaakst (zeer) tevreden (67\%).

In de opleidingssector Economie zijn de gediplomeerden met $18 \%$ gemiddeld het vaakst (zeer) ontevreden over de inhoud (wederom met marginale verschillen met de andere opleidingssectoren). Binnen de economische beroepsop- leiding Mediamanagement is de ontevredenheid over de inhoud het grootst ( $43 \%$ (zeer) ontevreden).

\section{Tevredenheid met de begeleiding}

Van de totale groep gediplomeerden is $45 \%$ (zeer) tevreden met de begeleiding (zie tabel 5). Er is echter tevens een aanzienlijk grote groep (31\%) die (zeer) ontevreden is over dit aspect van de gevolgde opleiding. Gediplomeerden van de technische beroepsopleiding Operator $C$ zijn van alle onderzochte beroepsopleidingen het vaakst (zeer) tevreden over de begeleiding (70\%), en gediplomeerden van de beroepsopleiding Medewerker design ${ }^{3}$ zijn hier het vaakst (zeer) ontevreden over (63\%) (zie Bijlage 2).

Tabel 5

Mate van tevredenheid over de begeleiding, per opleidingssector (\%)

\begin{tabular}{lrr}
\hline & $\begin{array}{c}\text { Begeleiding } \\
\text { (Zeer) ontevreden }\end{array}$ & (Zeer) tevreden \\
\hline Landbouw & 31 & 44 \\
Techniek & 32 & 42 \\
Economie & 32 & 44 \\
Gezondheidszorg & 28 & 47 \\
Gedrag\&Maatschappij & 30 & 46 \\
& & \\
Totaal & 31 & 45 \\
\hline
\end{tabular}

Gemiddeld zijn gediplomeerden van opleidingen in de sector Gezondheidszorg het vaakst (zeer) tevreden over de begeleiding (47\%), maar het verschil met de andere opleidingssectoren is marginaal. Van de beroepsopleiding binnen de Gezondheidszorg zijn gediplomeerden van Zorghulp het vaakst (zeer) tevreden over de begeleiding (54\%).

Wederom met marginale verschillen met de overige opleidingssectoren zijn de gediplomeerden van Techniek en Economie gemiddeld het vaakst (zeer) ontevreden over de begeleiding (beide 32\%). Binnen de technische opleidingssector zijn de gediplomeerden van de beroepsopleidingen Medewerker design ${ }^{4}$ (63\%) en DTP-er (55\%) het vaakst (zeer) ontevreden over de begeleiding. Binnen de economische opleidingssector is dit de beroepsopleiding Assistentmanager internationale handel (49\% (zeer) ontevreden).

\section{Tevredenheid met de kwaliteit van docenten}

lets meer dan de helft van de gediplomeerden (52\%) is (zeer) tevreden over de kwaliteit van de docenten (zie tabel 6). Een kwart is daarentegen (zeer) ontevreden over dit aspect van de gevolgde opleiding. Van alle onderzochte beroepsopleidingen zijn de gediplomeerden van de technische beroepsopleiding Medewerker stukadoren veruit het meest tevreden over de kwaliteit van de docenten (85\% (zeer) tevreden; 0\%

3. Binnen de beroepsopleiding Medewerker design zijn er zowel crebo's die onder de opleidingssector Techniek vallen, als crebo's die onder de opleidingssector Gezondheidszorg vallen.

4. Er zijn tevens crebo's die onder de beroepsopleiding Medewerker design vallen, die tot de opleidingssector Gezondheidszorg behoren. 
(zeer) ontevreden) (zie Bijlage 2). Gediplomeerden van de economische beroepsopleiding Applicatie- en mediaontwikkeling zijn met $46 \%$ daarentegen het vaakst (zeer) ontevreden over dit aspect.

Tabel 6

Mate van tevredenheid over de kwaliteit van de docenten, per opleidingssector (\%)

\begin{tabular}{lrr}
\hline & \multicolumn{2}{c}{ Docenten } \\
& (Zeer) ontevreden & (Zeer) tevreden \\
\hline Landbouw & 21 & 57 \\
Techniek & 24 & 53 \\
Economie & 26 & 51 \\
Gezondheidszorg & 24 & 52 \\
Gedrag\&Maatschappij & 27 & 50 \\
& & \\
Totaal & 25 & 52 \\
\hline
\end{tabular}

Gemiddeld is de tevredenheid over de kwaliteit van de docenten het hoogst voor de opleidingssector Landbouw (57\% (zeer) tevreden). Binnen deze opleidingssector zijn gediplomeerden van Assistent medewerker voedsel en leefomgeving het meest tevreden (77\% (zeer) tevreden; 5\% (zeer) ontevreden).

De tevredenheid over de kwaliteit van docenten is gemiddeld het laagst binnen de opleidingssector Gedrag\&Maatschappij (27\% (zeer) ontevreden). De ontevredenheid over dit aspect van de gevolgde opleiding is het hoogst onder de gediplomeerden van de beroepsopleiding Sociaal-maatschappelijk dienstverlener (32\% (zeer) ontevreden).

\section{Overwogen voortijdig te stoppen}

We hebben nu een beeld van de mate waarin gediplomeerden terugkijkend op hun gevolgde opleiding tevreden zijn met verschillende aspecten van de gevolgde opleiding. We gaan nu bestuderen in hoeverre de gediplomeerden in het algemeen tevreden waren met de opleiding terwijl ze die opleiding nog aan het volgen waren. Dit doen we door te kijken naar de antwoorden op de vraag "Heeft $u$ tijdens de opleiding er serieus aan gedacht om met de opleiding te stoppen?". In totaal heeft $17 \%$ van de gediplomeerden geantwoord er inderdaad serieus aan te hebben gedacht om met de opleiding te stoppen. Dat betekent dat de overgrote meerderheid $(83 \%)$ daar niet serieus aan heeft gedacht. Het aandeel dat er tijdens de opleiding serieus aan heeft gedacht om met de opleiding te stoppen is het hoogst onder de gediplomeerden van de beroepsopleiding Natuur en leefomgeving (38\%), die binnen de opleidingssector Landbouw valt (zie Bijlage 3). Het aandeel gediplomeerden dat er serieus aan heeft gedacht om te stoppen is het kleinst binnen de Gezondheidszorgberoepsopleiding Schoonmaak en glazenwassen (०\%).
Tabel 7

Percentage gediplomeerden dat er tijdens de opleiding serieus aan heeft gedacht om met de opleiding te stoppen, per opleidingssector (\%)

\begin{tabular}{lr}
\hline Landbouw & 21 \\
Techniek & 16 \\
Economie & 18 \\
Gezondheidszorg & 17 \\
Gedrag\&Maatschappij & 16 \\
Totaal & \\
\hline
\end{tabular}

Vergeleken met de andere opleidingssectoren is het aandeel gediplomeerden dat er tijdens de opleiding serieus aan heeft gedacht om met de opleiding te stoppen het hoogst voor de opleidingssector Landbouw (21\%).

Het aandeel gediplomeerden dat er tijdens de opleiding serieus aan heeft gedacht om met de opleiding te stoppen is het kleinst voor de opleidingssectoren Techniek en Gedrag\&Maatschappij (beiden 16\%). Binnen de opleidingssector Gedrag\&Maatschappij is dit aandeel het kleinst binnen de beroepsopleiding Medewerker sociale zekerheid (12\%).

\section{Zelfde opleiding niet opnieuw kiezen}

Tot slot bestuderen we het aandeel gediplomeerden dat aangeeft achteraf gezien de door hen gevolgde BOL/ BBL-opleiding niet opnieuw te zullen kiezen. Zij zouden achteraf gezien een andere opleiding kiezen, of zelfs helemaal niet gaan studeren. Ook dit kan gezien worden als een samenvattende indicator van de tevredenheid over de gevolgde opleiding.

Van de totale groep gediplomeerden geeft $27 \%$ aan achteraf gezien niet dezelfde opleiding opnieuw te kiezen (zie tabel 8). De meerderheid (73\%) geeft dus aan achteraf gezien dezelfde opleidingskeuze te zullen maken. Van alle onderzochte beroepsopleidingen is het aandeel gediplomeerden dat aangeeft achteraf gezien niet dezelfde opleiding te kiezen het hoogst onder de gediplomeerden van de technische beroepsopleiding Medewerker versdetailhandel (54\%), en het kleinst voor de beroepsopleiding Pedicure (o\%) die onder de opleidingssector Gezondheidszorg valt (zie Bijlage 3).

Tabel 8

Percentage gediplomeerden dat aangeeft achteraf gezien niet dezelfde opleiding opnieuw te kiezen, per opleidingssector (\%)

\begin{tabular}{ll}
\hline Landbouw & 32 \\
Techniek & 25 \\
Economie & 32 \\
Gezondheidszorg & 22 \\
Gedrag\&Maatschappij & 27
\end{tabular}


De opleidingssector Gezondheidszorg wordt ook als totaal goed beoordeeld op dit aspect: het aandeel gediplomeerden dat aangeeft achteraf gezien niet dezelfde opleidingskeuze te maken is gemiddeld het laagst van alle opleidingssectoren (22\%).

Het aandeel gediplomeerden dat aangeeft achteraf gezien niet zelfde opleiding te kiezen is gemiddeld het hoogst voor de opleidingssectoren Landbouw en Economie (beide 32\%). Binnen de opleidingssector Landbouw wordt de beroepsopleiding Natuur en vormgeving het slechtst beoordeeld ( $49 \%$ zou niet dezelfde keuze maken), en binnen de opleidingssector Economie zijn dat de beroepsopleidingen Arbeidsmarktgekwalificeerd assistent ${ }^{5}$ (44\%) en Applicatie- en mediaontwikkeling (43\%).

5. Er zijn tevens crebo's die onder de beroepsopleiding Arbeidsmarktgekwalificeerd assistent vallen, die tot de opleidingssector Landbouw behoren. 


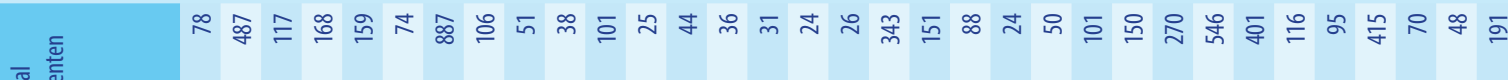
焉 离

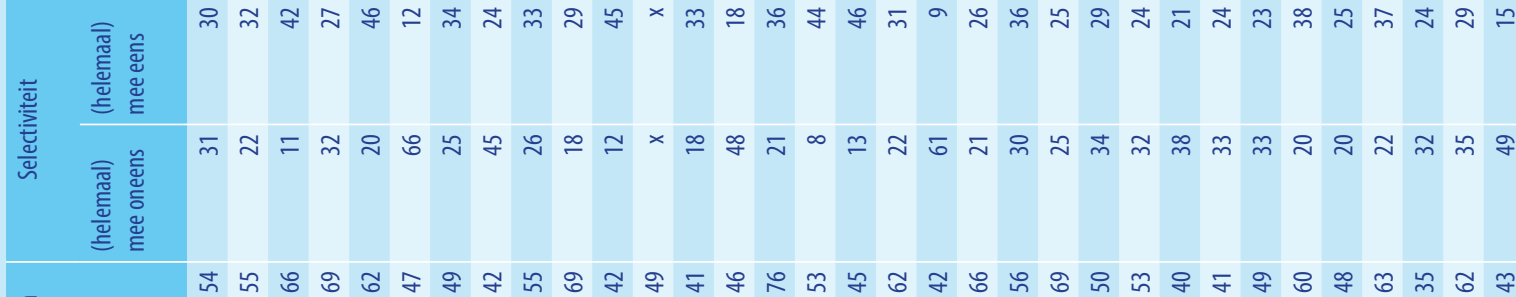

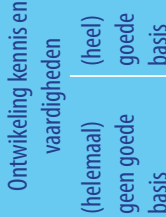
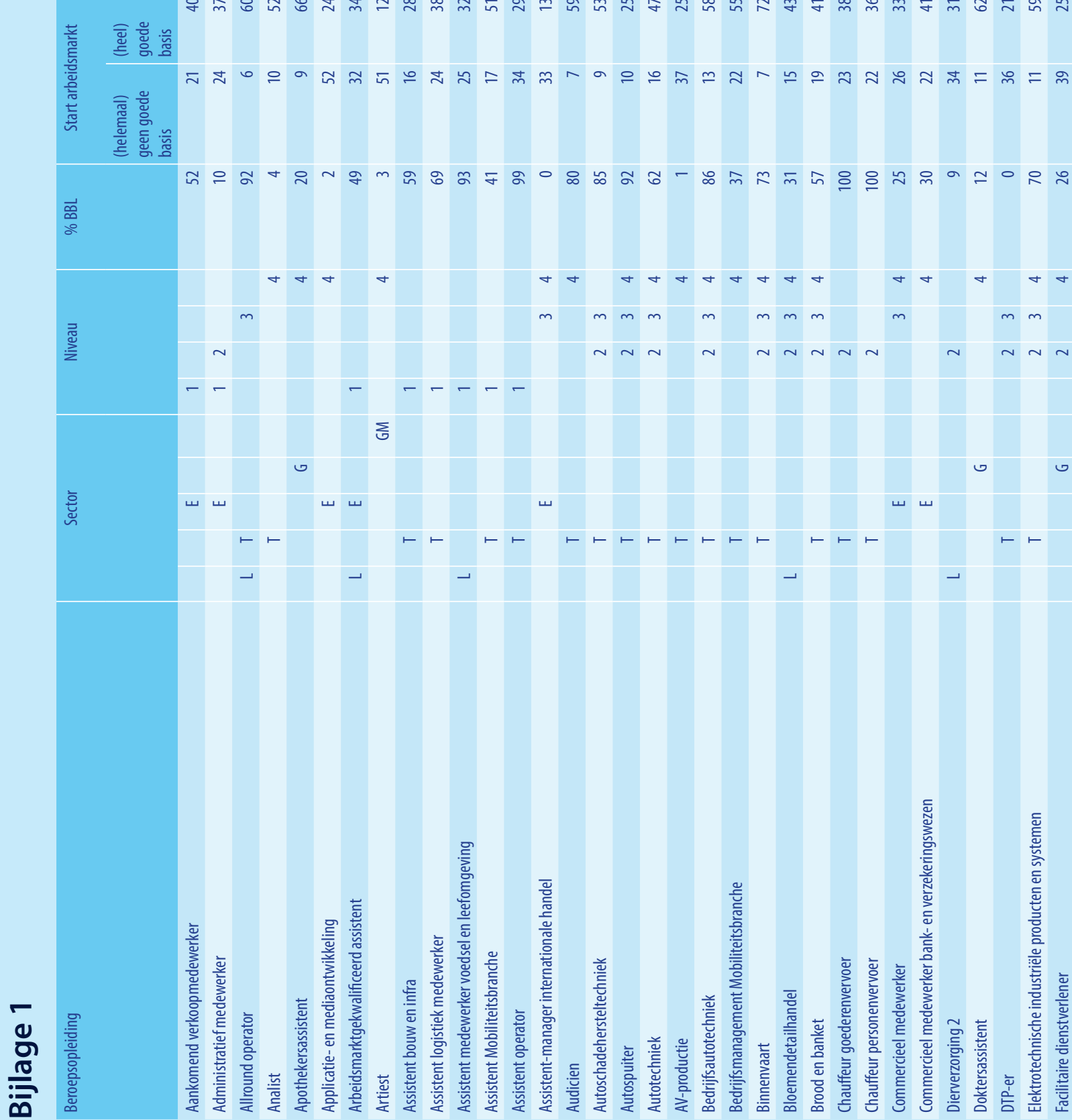
8 Oordelen over beroepsopleidingen in het $\mathrm{MBO}$

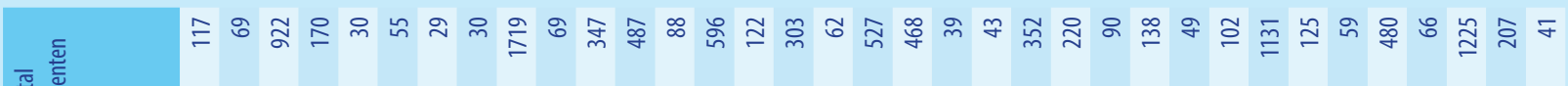
焉 $\frac{\bar{d}}{\overline{0}}$

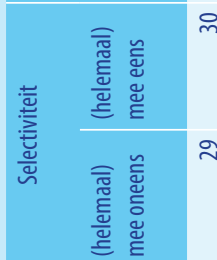

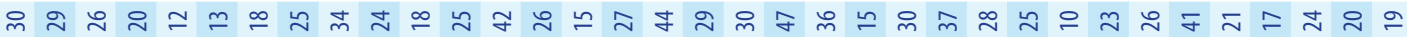

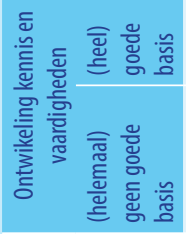
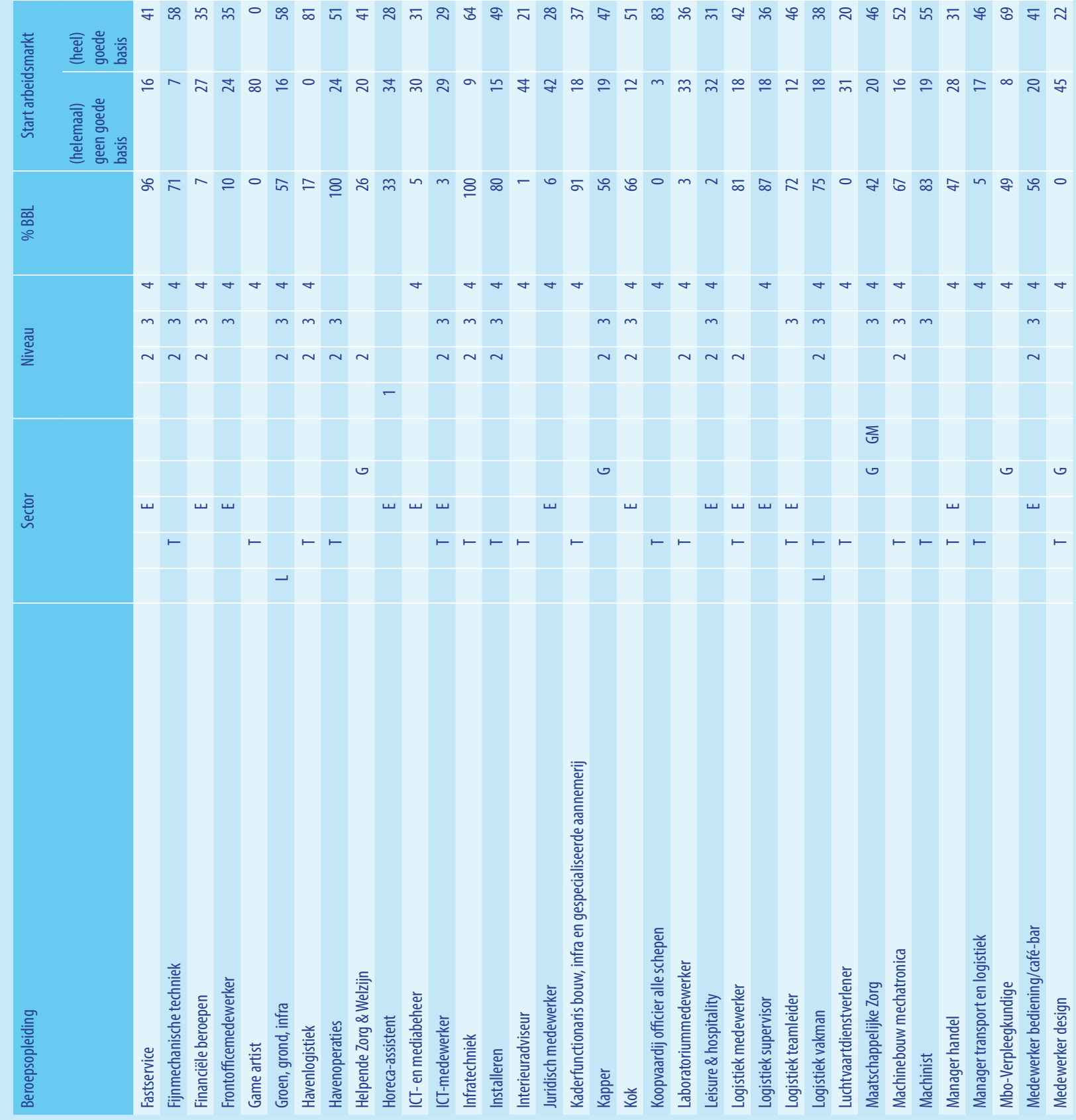
牙 焉 竞

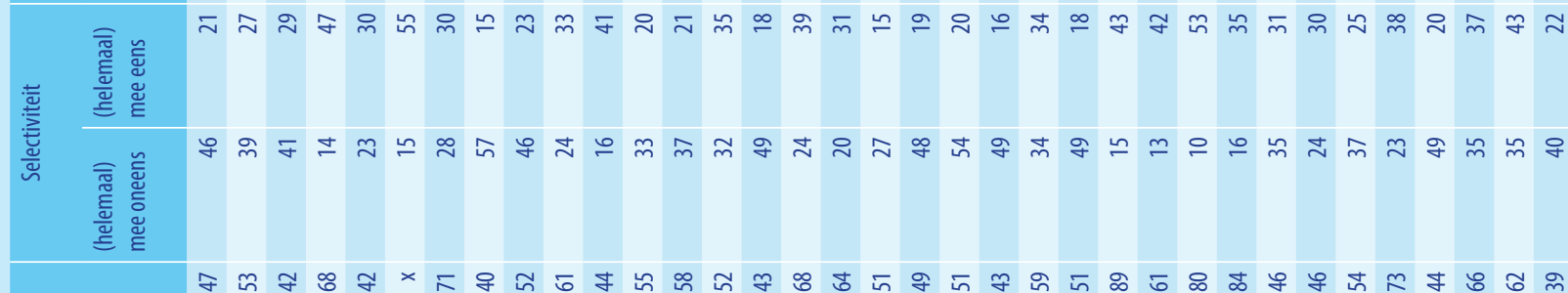

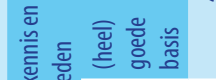
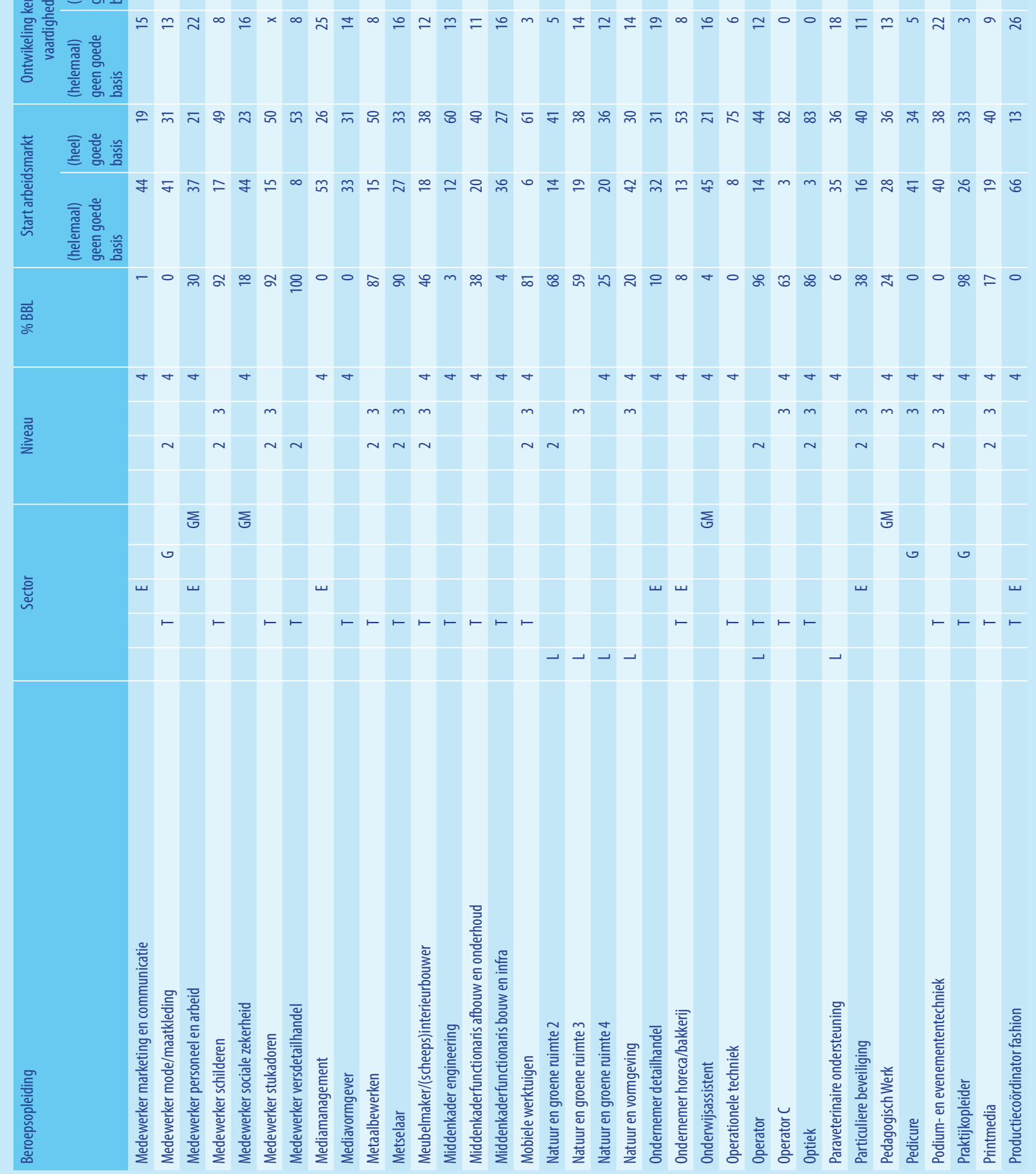


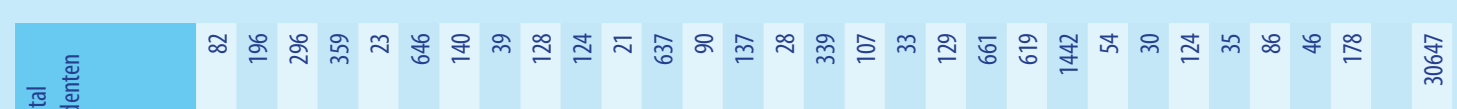

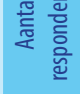

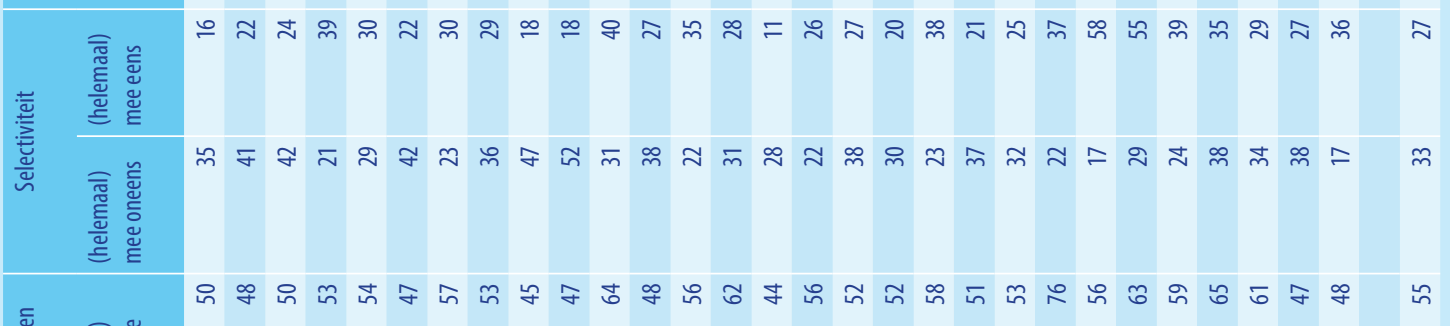

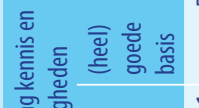

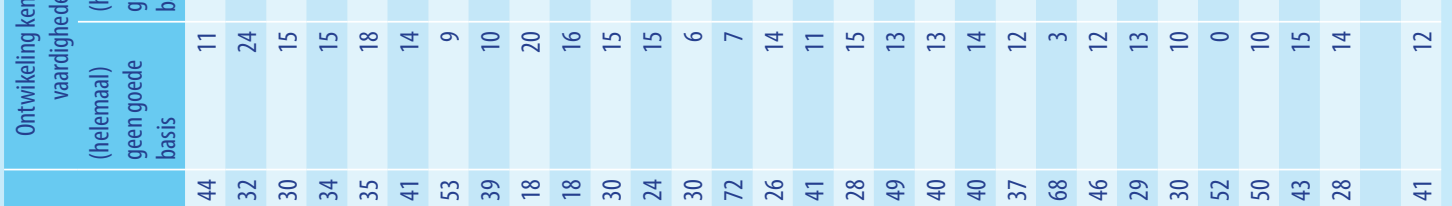

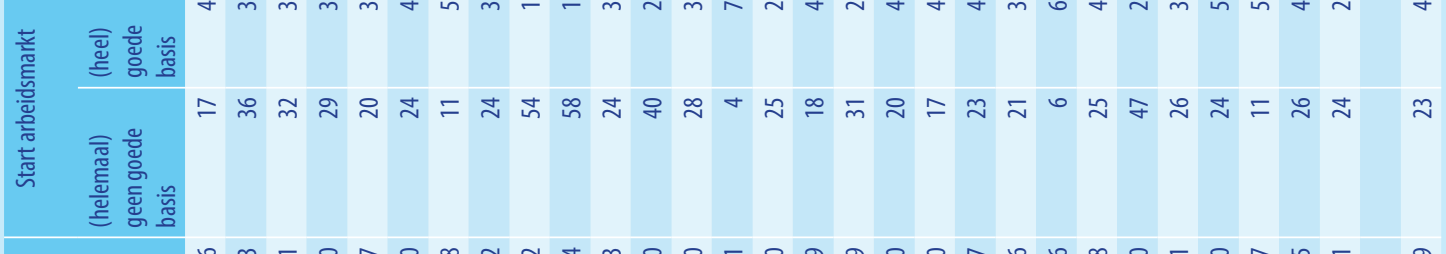

$\stackrel{m}{\circ}$

$\stackrel{\Xi}{\stackrel{\Xi}{\Sigma}}$

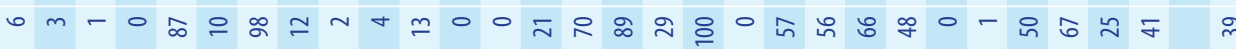

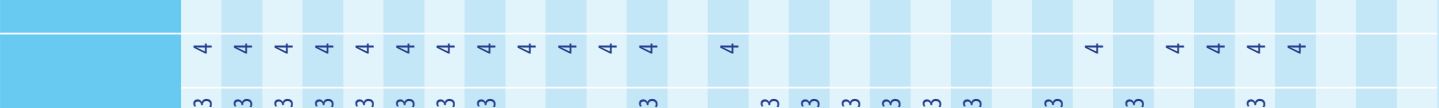

총 츠
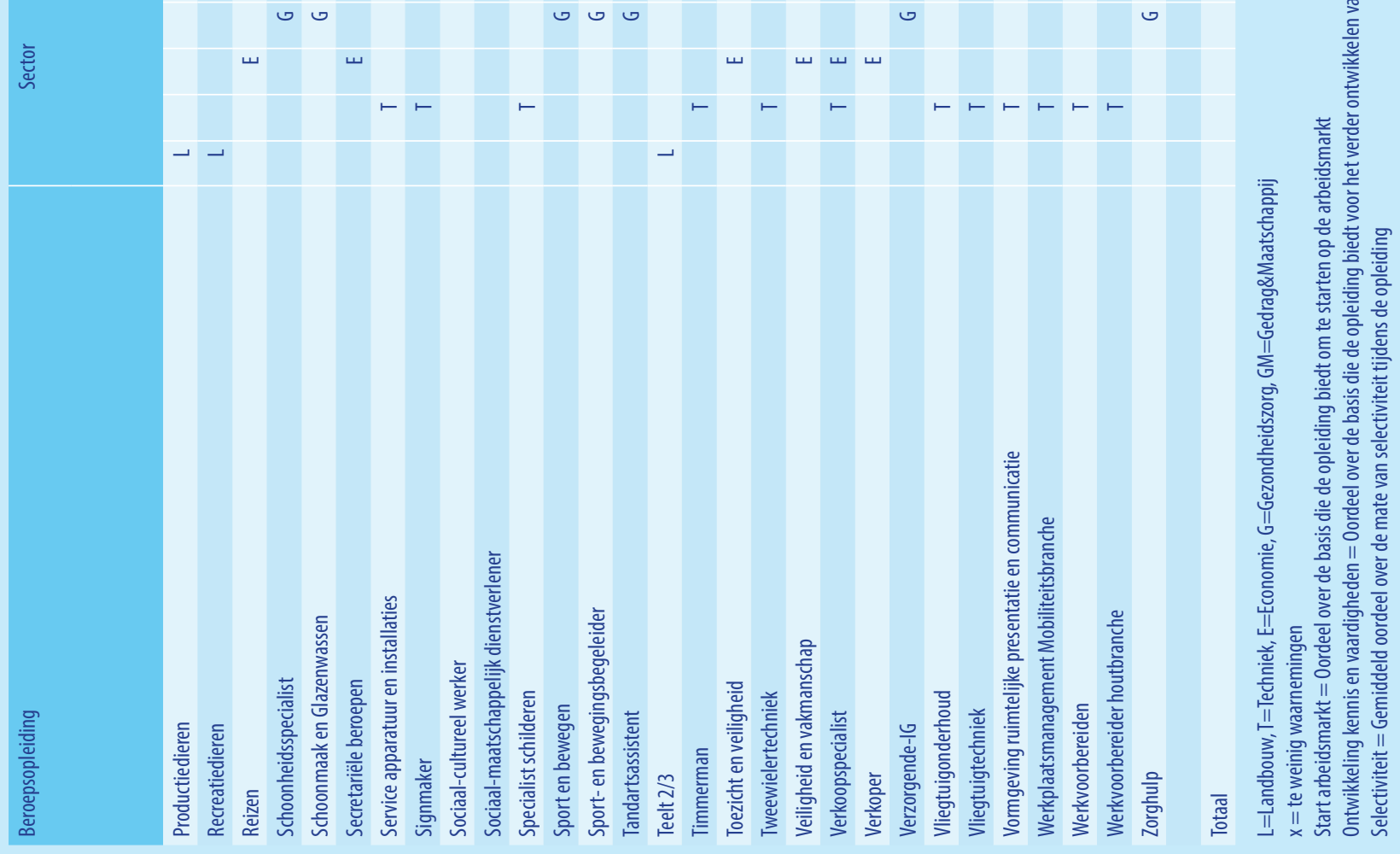


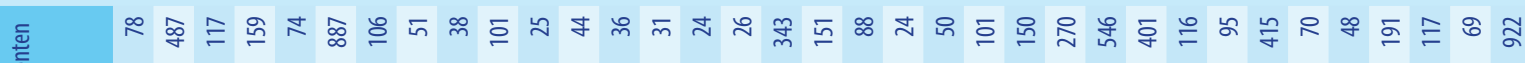
离 离

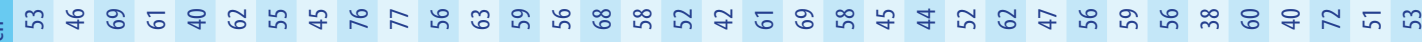

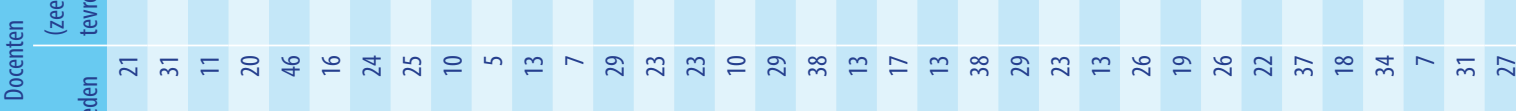
巡产芒

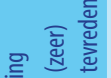
离 芯芯 芯產 믈 $\neg \simeq \infty$ 윰 离 क्ष

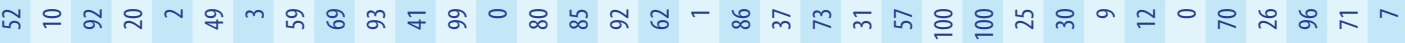

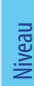
총

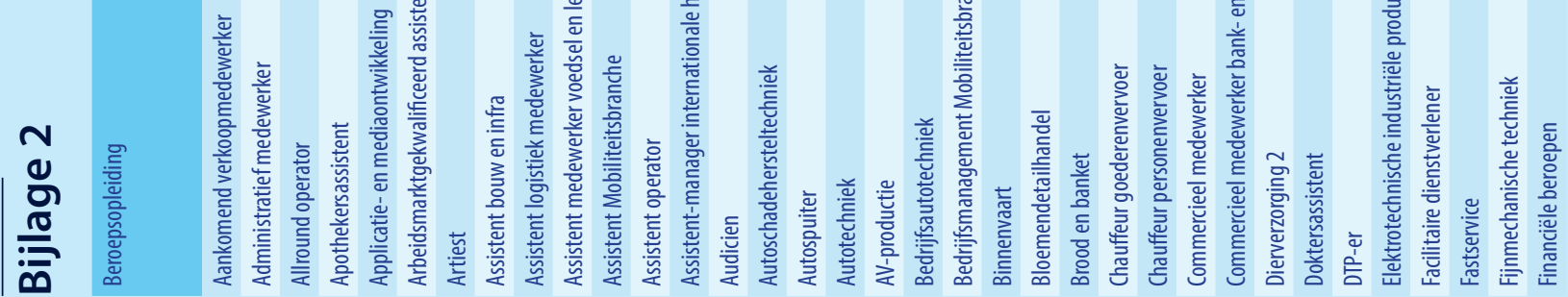




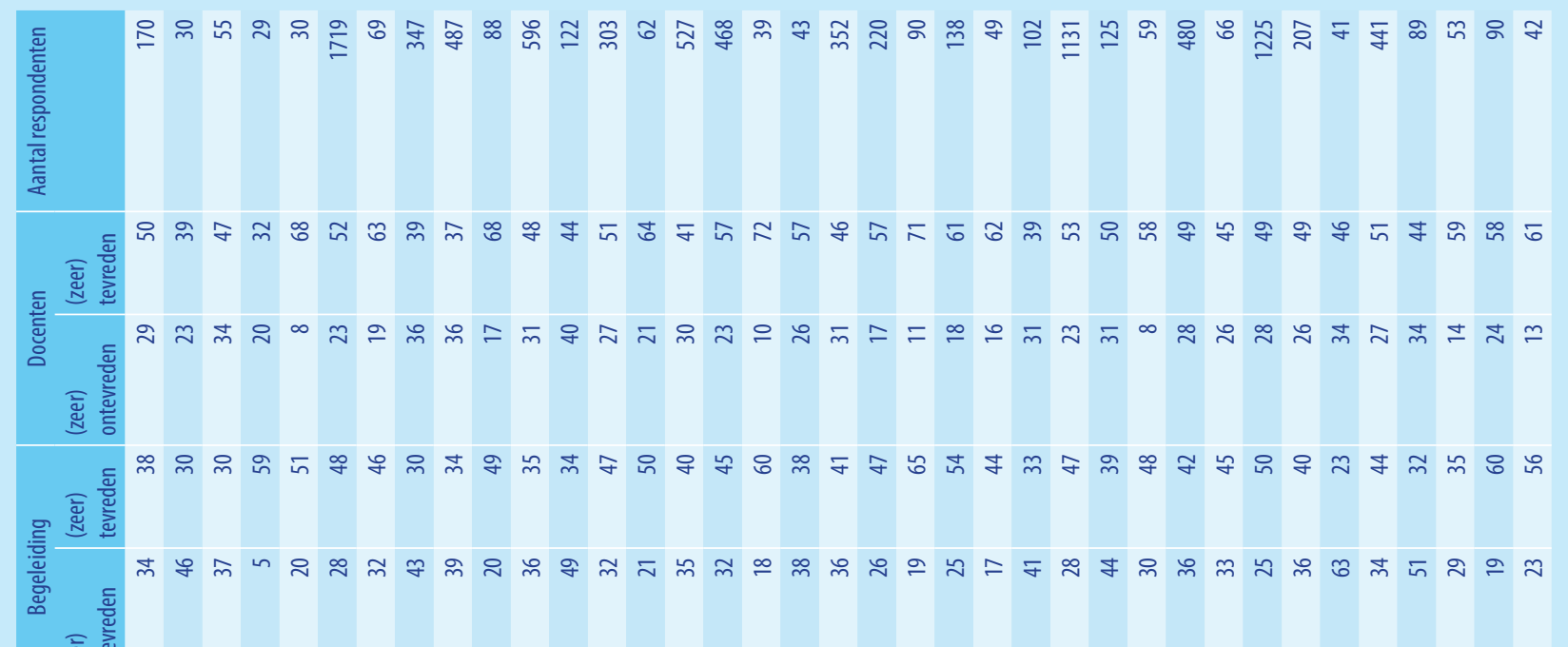

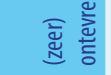
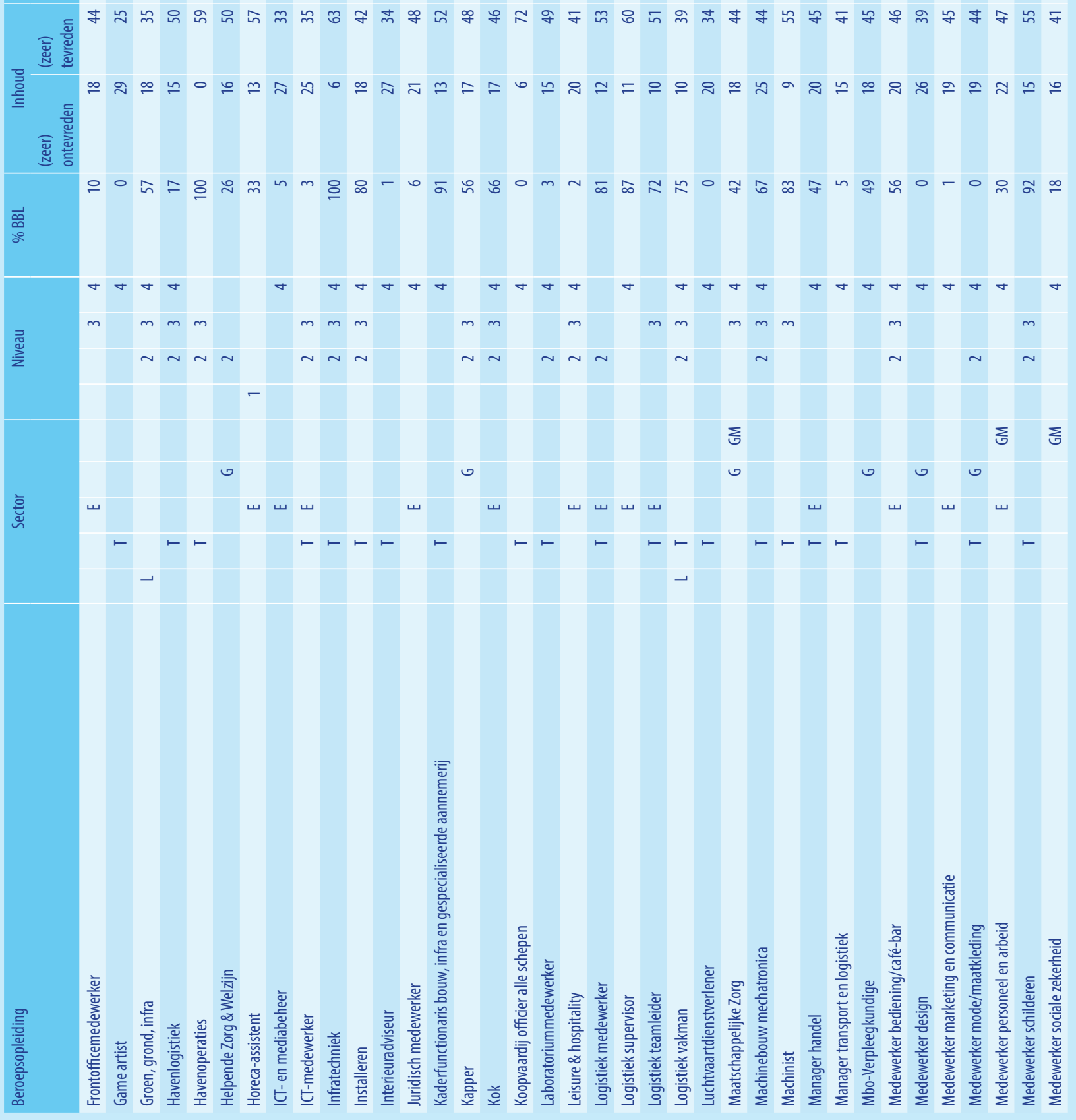


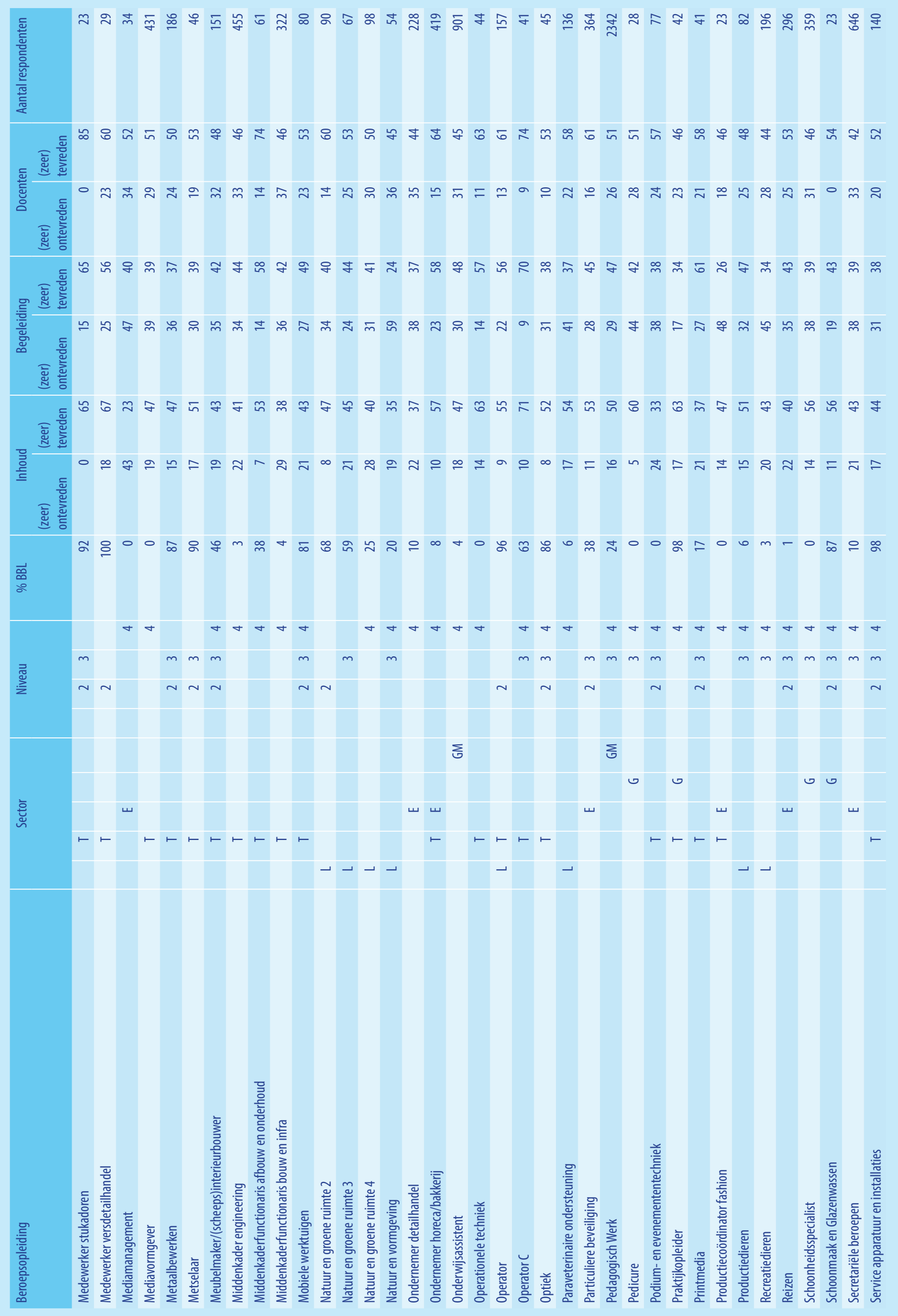



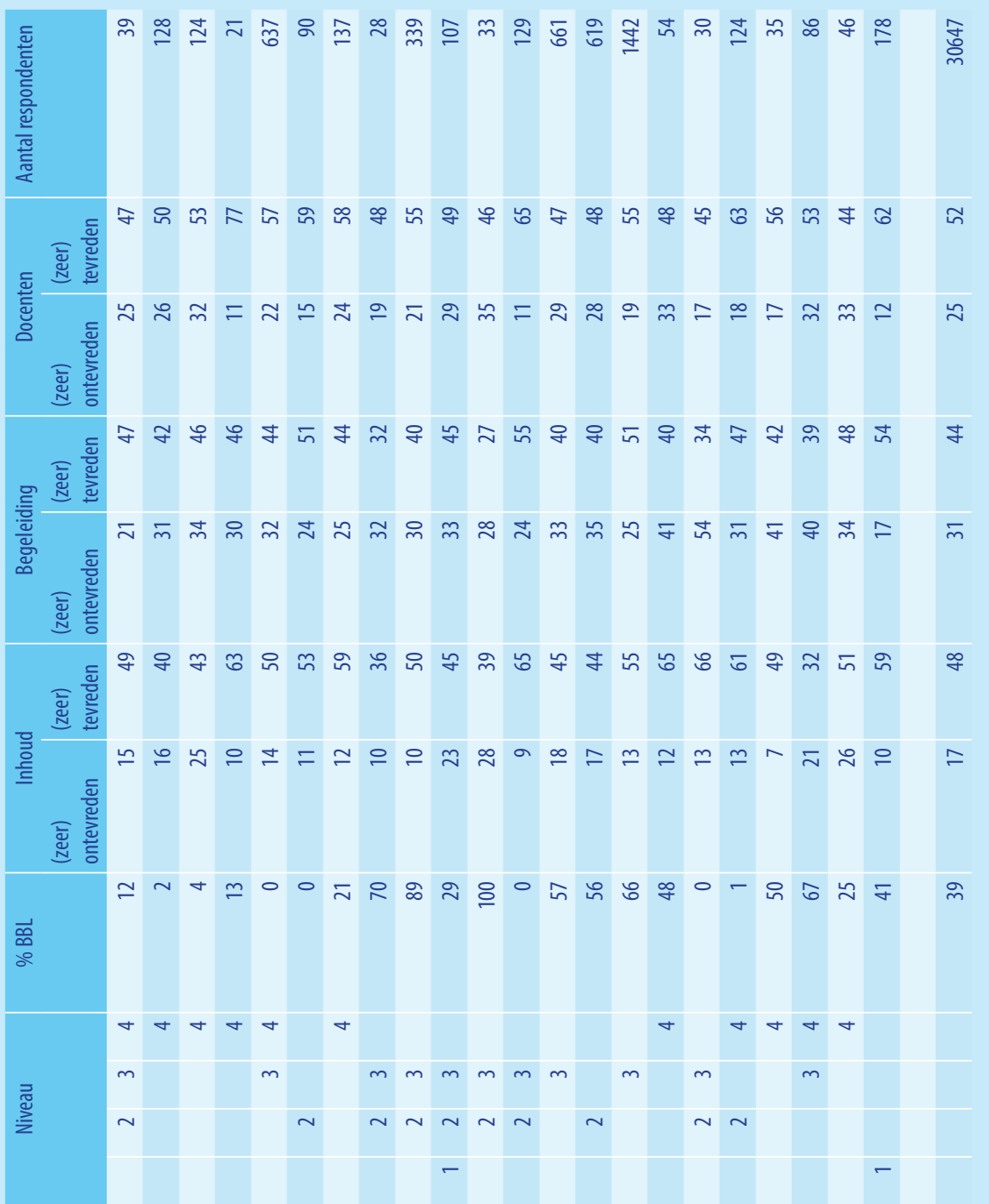

롱 ร్

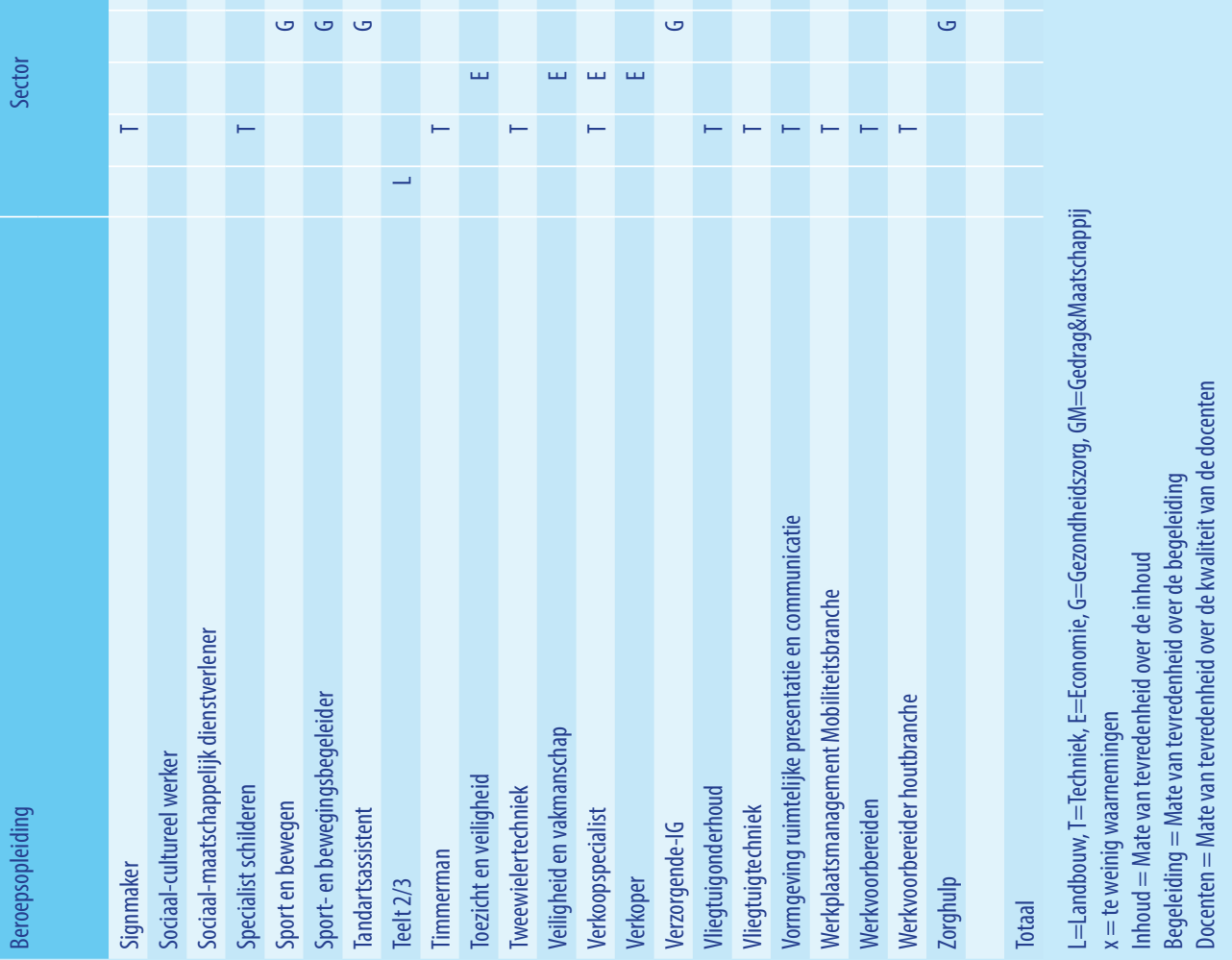




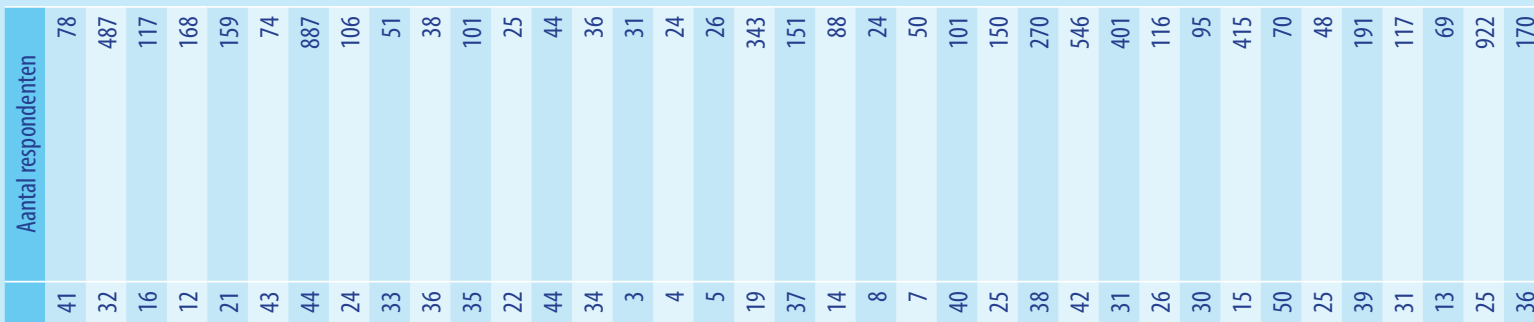

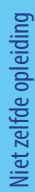

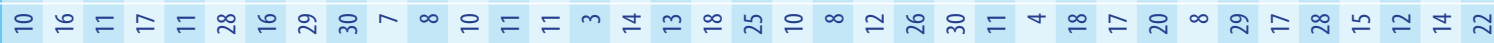

흘
흘
흘
흥

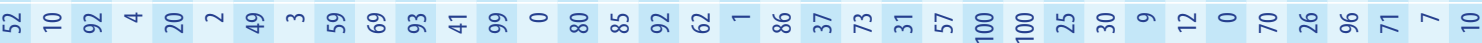

$\overrightarrow{\mathrm{a}}$

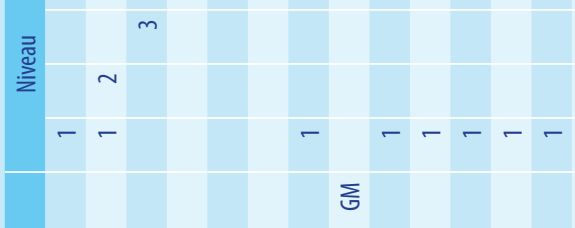

言山

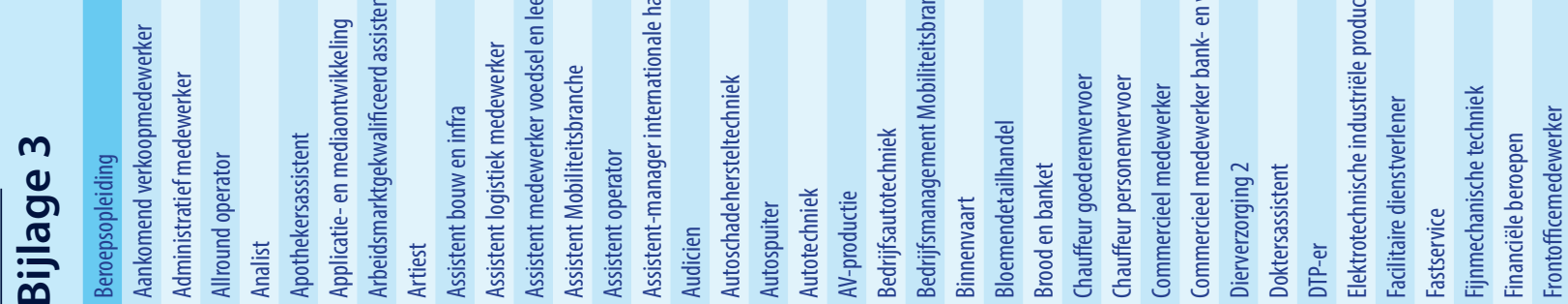




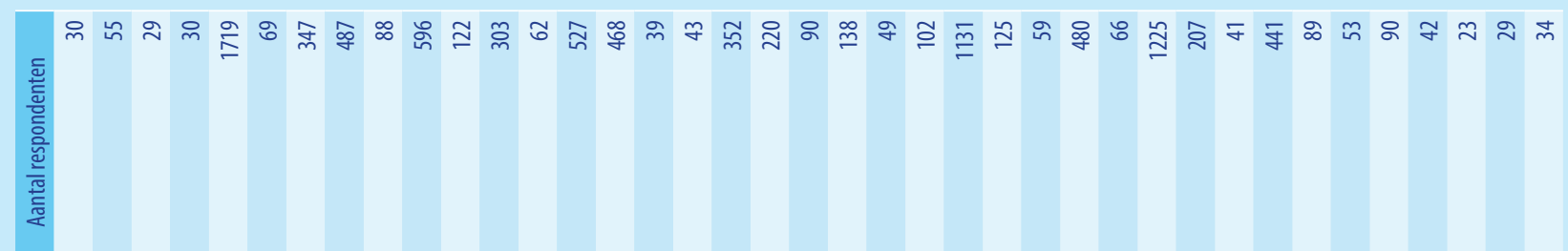
广 


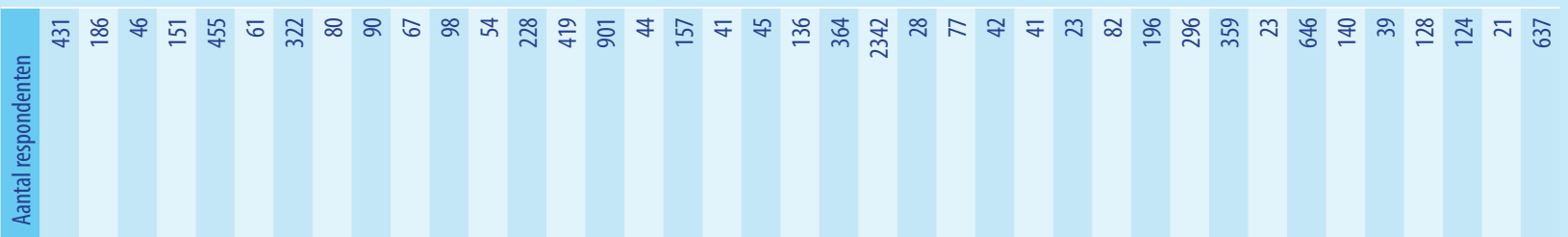

ฟ $ฟ$ ฟ

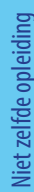

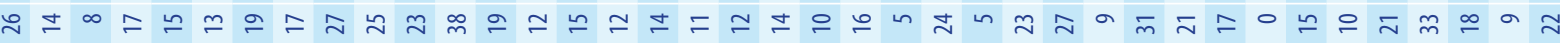

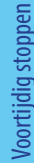

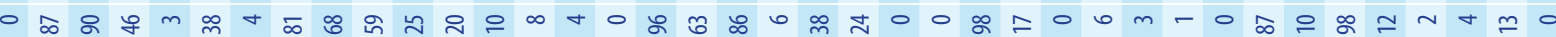

형

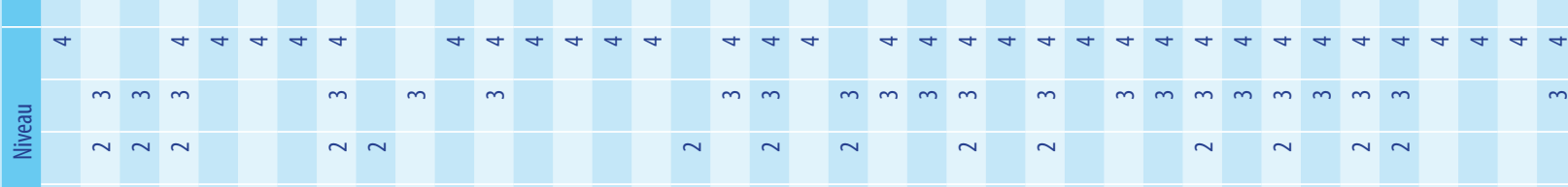

¿

乏

కృㅎํ

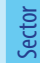

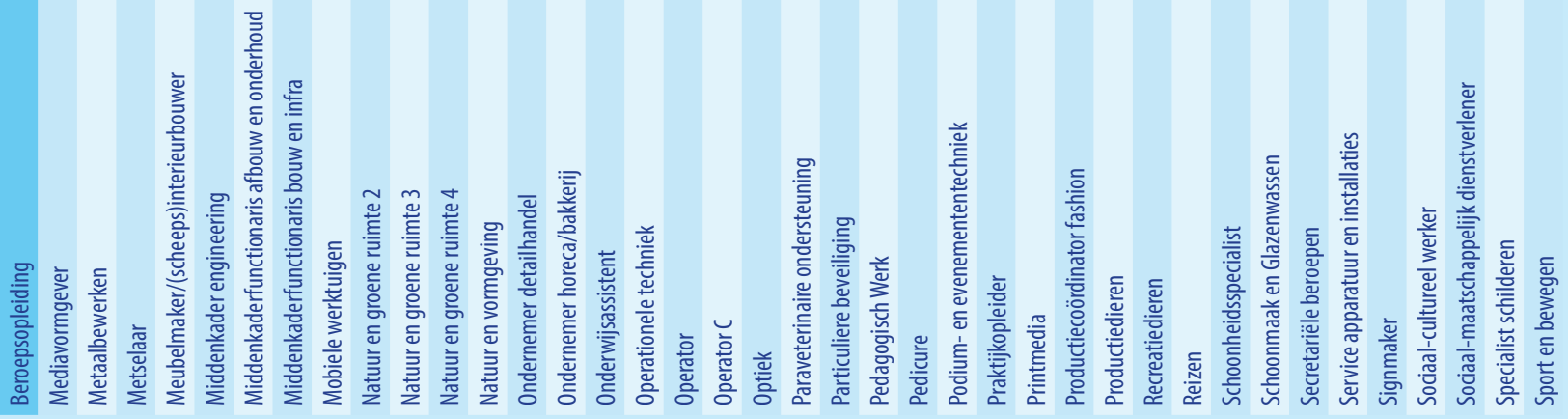




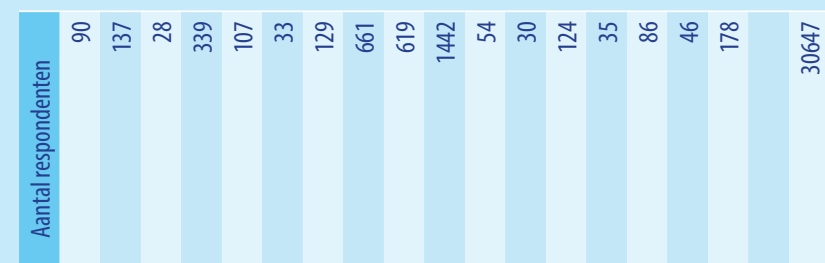

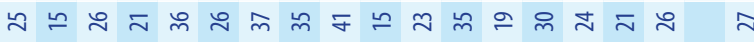

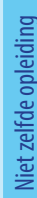

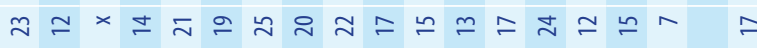

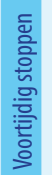

- స R வ

$\overrightarrow{0}$

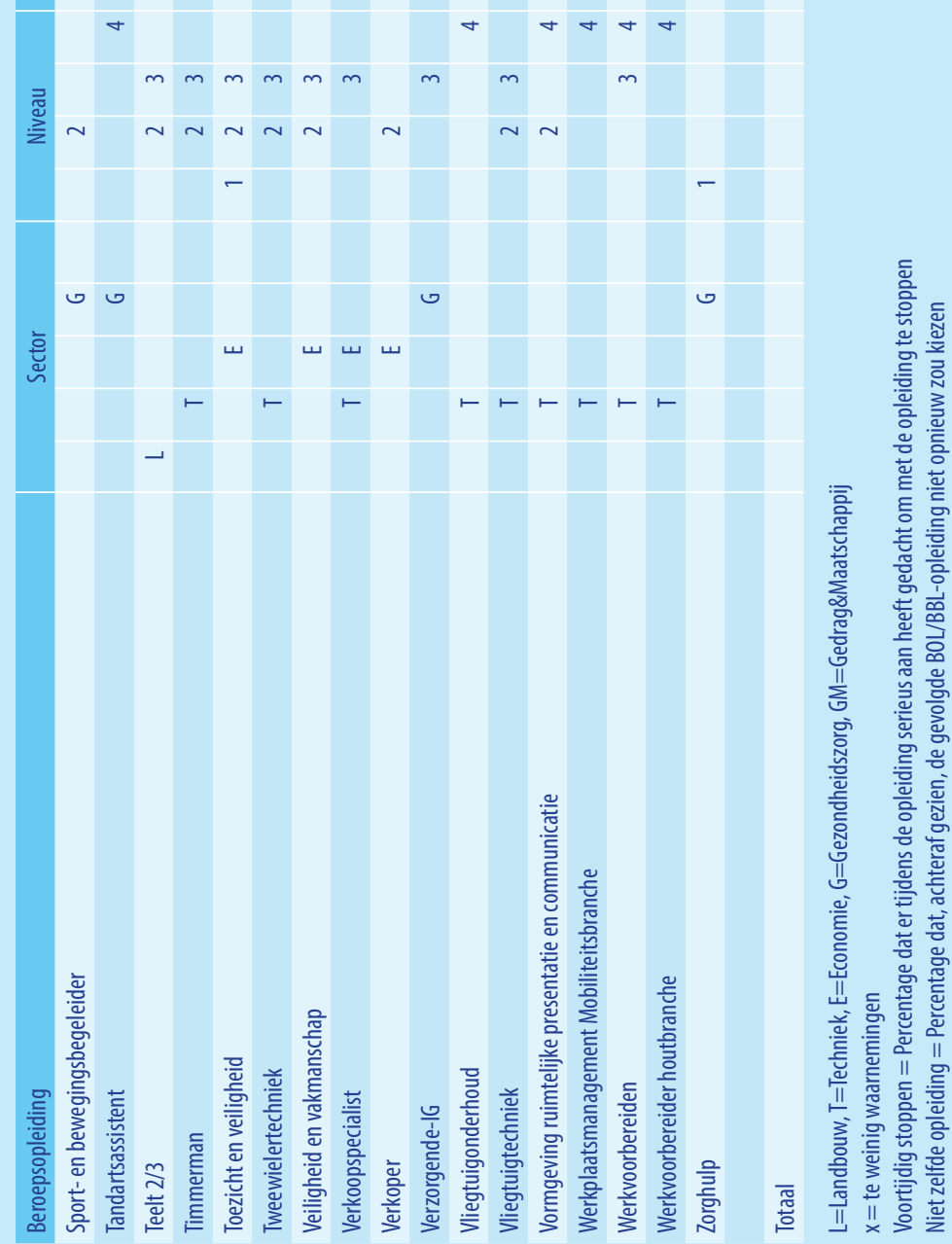


Researchcentrum voor Onderwijs en Arbeidsmarkt

Postbus 616

6200 MD Maastricht

$\mathrm{T}+31433883647$

F +31 433884914

secretary-roa-sbe@maastrichtuniversity.nl

www.roa.nl

Maastricht University

School of Business and Economics 